\title{
PENGUATAN KESADARAN PERAN PEREMPUAN DALAM KEHIDUPAN SOSIAL DI DESA LOLOAN KECAMATAN BAYAN LOMBOK UTARA
}

\author{
Saparudin \\ Dosen Prodi. IPS FTK UIN Mataram
}

\begin{abstract}
Abstrak. Kegiatan pengabdian masyarakat ini bertujuan untuk membantu menguatkan kesadaran peran perempuan setempat dalam kehidupan sosial melalui pemberdayaan bidang wirausaha, pendidikan dan ketrampilan (life skill).

Adapun strategi yang digunakan adalah: Pertama, yaitu melakukan mapping sosia/ dengan cara silaturrahmi atau kunjungan ke rumah-rumah, sehingga diketahui aktifitas sehari-hari mereka dan berbagai persoalan yang dihadapi didukung dengan transeks (telusur wilayah). Kedua, perencanaan program yaitu bersama-sama menentukan rencana kegiatan yang akan dilaksanakan untuk menyelesaikan persoalan-persoalan yang telah terumuskan. Ketiga pelaksanaan program. Keempat, evaluasi program, yaitu mengetahui seberapa jauh hasil yang telah dicapai dalam pelaksanaan program.

Kegiatan Pelatihan cukup berhasil, walaupun dari jumlah beserta hanya tidak sebanyak yang telah direncanakan akan tetapi jumlah pertanyaan yang muncul selama diskusi cukup banyak. Pada peserta sangat antusius dengan pelatihan yang dilakukan oleh tim pengabdian.
\end{abstract}

Kata Kunci: Penguatan, Kesadaran, Peran Perempuan

\section{PENDAHULUAN}

Perempuan merupakan bagian tak terpisahkan dalam sebuah masyarakat, tak terkecuali dalam masyarakat miskin. Perempuan memiliki potensi yang sama dengan laki-laki untuk memberikan kontribusi bagi pembangunan masyarakat. Namun pada kenyataannya, perempuan masih belum diberi peran yang lebih, bahkan juga terpinggirkan.

Kiprah perempuan dalam perekonomian keluarga dan nasional menjadi salah satu bagian penting dalam pembangunan secara keseluruhan. Seiring dengan bertambahnya pendapatan perempuan atau akses perempuan terhadap sumber-sumber daya ekonomi melalui usaha ini, maka kemampuan dan kesempatan mereka bernegosiasi dalam rumah tangga pun meningkat. Posisi tawar mereka berubah dan pendapat mereka mulai diperhitungkan dalam setiap proses pengambilan keputusan dalam rumah tangga. Partisipasi perempuan merupakan hal yang sangat penting untuk mencapai tujuan pembangunan.

Upaya pengembangan usaha mikro yang dilakukan oleh perempuan ini menjadi penting, karena perempuan berhadapan dengan kendalakendala tertentu 
yang dikenal dengan istilah "tripple burden of women", yaitu ketika mereka 'diminta' menjalankan fungsi reproduksi, produksi, sekaligus fungsi sosial di masyarakat pada saat yang bersamaan. Hal tersebut menyebabkan kesempatan perempuan untuk memanfaatkan peluang ekonomi yang ada menjadi sangat terbatas. Sebagian besar perempuan masih berkiprah di sektor informal atau pekerjaan yang tidak memerlukan kualitas pengetahuan dan ketrampilan spesifik. Pekerjaanpekerjaan ini biasanya kurang memberikan jaminan perlindungan secara hukum dan jaminan kesejahteraan yang memadai, disamping kondisi kerja yang memprihatinkan serta pendapatan yang rendah.

Sebagai anggota masyarakat, saat seorang perempuan melihat bahwa masyarakatnya mengalami gangguan stabilitas atau terkena penyakit, maka ia harus segera mencari jalan penanggulangannya. Bahkan, dalam kondisi tertentu, perempuan diharuskan terjun ke masyarakat, misalnya, harus ada perempuan yang bekerja sebagai

Memperhatikan pelbagai kasus atau peristiwa yang terjadi di tanah air, maka tidak benar bila kita hendak memposisikan perempuan sebagai manusia kelas dua. Hal yang harus dikerjakan adalah bagaimana memposisikan perempuan secara adil dan setara dalam segala aspek kehidupan, karena dalam kenyataan banyak laki-laki tidak lebih baik dari perempuan, tetapi perempuan sebagian besar dipandang sebagai pihak yang tidak pada "takdirnya" ketika masuk dalam ranah publik-ekonomi, politik, budaya dan agama. Tentu pandangan ini tidak adil pada perempuan, karenanya harus disingkirkan.

Meretas persoalan ini tentu dibutuhkan peran dari semua pihak dan lembaga secara simultan dan berkesinambungan. Peran lembaga pendidikan pun harus hadir dalam menemukan solusi atas persoalan yang dihadapi kaum perempuan di Desa Loloan khususnya dan masyarakat Indonesia pada umumnya. Lembaga pendidikan yang bsia bersentuhan langsung dengan persoalan ini yaitu perguruan tinggi melalui salah satu dari tridharma perguruan tinggi yaitu pengabdian pada masyarakat.

Kondisi perempuan dalam kehidupan social masyarakat Desa Loloan pada saat ini bisa dikatakan sebagai manusia yang hidup dalam dilematis. Di satu sisi perempuan dituntut untuk berperan dalam semua sektor, tetapi di sisi lain kondisi 
Transformasi, Vol. 13, No. 1, Januari 2017: 62 - 79

perempuan Desa Loloan dengan keterbatasan pengetahuan untuk mengembangkan perannya dalam kehidupan sosial. Selain itu wanita desa setempat juga dibatasi perannya dalam kehidupan social karena tuntutan agar wanita tidak melupakan kodrat mereka sebagai wanita. Situasi ini terutama dihadapi oleh wanita yang hidup di lingkungan keluarga yang masih memegang teguh kebudayaan setempat.

Wanita tersebut di satu sisi merasa terpanggil untuk mendarmabaktikan bakat dan keahliannya bagi perkembangan masyarakat setempat, di pihak lain mereka merasa dihantui oleh opini di kalangan masyarakat yang beranggapan bahwa perempuan sebagai ibu rumah tangga yang berkarier, merupakan wanita yang tidak akan berhasil dalam membina rumah tangganya, karena perhatian mereka tidak akan terfokus pada satu tugas pokok, yaitu sebagai pengelola rumah tangga, akan tetapi perhatiannya terbagi kepada dua tugas yang kesemuanya menuntut untuk diutamakan dalam pelaksanaannya.

Cerminan dilematis wanita seperti di atas, pada masyarakat Desa Loloan yang sampai sekarang masih ada, misalnya saja adanya anggapan bahwa perempuan itu adalah sebagai pengurus rumah tangga. Selain itu ada ungkapan yang menyatakan, bahwa suami adalah "guru laki-laki" yang artinya suami bertanggung jawab terhadap kesejahteraan material juga berkewajiban seperti halnya guru bagi istrinya agar tidak berbuat sesuatu yang tidak sesuai dengan ajaran agama ataupun adat. Padahal sebenarnya dalam kehidupan rumah tangga, tidak hanya suami saja yang sebagai guru istri, tapi istri juga bisa sebagai guru suami jika berbuat sesuatu yang tidak sesuai dengan ajaran agama dan adat, karena dalam proses sosialisasi keluarga keduanya (suami dan istri) sama-sama mempunyai peran yang penting untuk saling mendidik agar suami dan istri tersebut beserta anggota keluarga yang lain tidak terjerumus dalam dosa-dosa karena melanggar norma-norma agama.

\section{PEMBAHASAN}

\section{A. Peran Perempuan}

Kepedulian terhadap eksistensi perempuan adalah dengan adanya instruksi Presiden RI No.9 tahun 2000 tentang "Pengarusutamaan Gender dalam Pembangunan Nasional". Sasaran strategi pengarusutamaan gender 
(PUG) adalah upaya untuk mencapai kesetaraan dan keadilan gender, melalui kebijakan dan program yang memperhatikan pengalaman, aspirasi, kebutuhan, dan permasalahan perempuan dan laki-laki ke dalam seluruh kebijakan di berbagai bidang kehidupan dan pembangunan.

Penguatan dari pemerintah tersebut dapat dikatakan memberi warna terang tentang keharusan para stakeholder untuk tidak menyampingkan posisi perempuan dalam setiap kegiatan pembangunan. Dan tugas utama penggiat peningkatan kesetaraan perempuan adalah mempelajari lalu memperbaiki cara berpikir perempuan itu sendiri agar mau berubah. Hal ini berkaitan dengan Sosiolog feminis yang menyatakan bahwa perempuan merasakan diri mereka demikian dibatasi oleh status mereka sebagai perempuan sehingga gagasan yang mereka bangun untuk kehidupan mereka nyaris menjadi teori tanpa makna. Perempuan berpengalaman merencanakan dan bertindak dalam rangka mengurus berbagai kepentingan, kepentingan mereka sendiri dan kepentingan orang lain; bertindak atas dasar kerjasama, bukan karena keunggulan sendiri; dan mungkin mengevaluasi pengalaman dari peran penyeimbang mereka bukan sebagai peran yang penuh konflik, tetapi sebagai respon yang lebih tepat terhadap kehidupan sosial ketimbang kompertementalisasi peran.

Pemahaman pentingnya peran perempuan diperkuat dengan kenyataan bahwa afirmasi berupa instruksi Presiden tentang Pengarusutamaan Gender dalam Pembangunan Nasional, cenderung diterima dengan dilema oleh penggiat kesetaraan gender, satu pihak peran perempuan perlu diperhatikan dan diperkuat oleh pemerintah, di satu pihak pemerintah seakan memberi perhatian tanpa mengetahui kebutuhan perempuan secara sosial budaya. Bila penggiat kesetaraan gender masih dilema dengan afirmasi dari pemerintah, bagaimana dengan perempuan awam pengetahuan lainnya, tetesan kebijakan pemerintah untuk

Pada umumnya masyarakat di Indonesia, pembagian kerja antara lelaki dan perempuan menggambarkan peran perempuan. Basis awal dari pembagian kerja menurut jenis kelamin ini tidak diragukan lagi terkait dengan 
Transformasi, Vol. 13, No. 1, Januari 2017: 62 - 79

kebedaan peran lelaki dan perempuan dalam fungsi reproduksi. Dalam masyarakat mempresentasikan peran yang ditampilkan oleh seorang perempuan.

Dalam perkembangan kajian peran perempuan, konsep peran seks (sex roles) memberi makna tersendiri. Peran seks adalah seperangkat atribut dan ekspektasi yang diasosiasikan dengan perbedaan gender, dengan hal ihwal menjadi laki-laki atau perempuan dalam masyarakat. Menurut teori fungsionalisme (functionalism), peran seks (seperti peran yang lain) merefleksikan norma-norma sosial yang bertahan dan merupakan pola-pola sosialisasi (socialization). Norma yang cenderung terjadi dewasa ini adalah hubungan antara laki-laki dan perempuan telah berubah seiring dengan perkembangan secara bertahap perihal keluarga yang berkesetaraan.

\section{B. Peran Perempuan dalam Keluarga}

Sebagaiman kita ketahui, keluarga itu sendiri dapat dilihat dalam arti kata yang sempit yaitu sebagai keluarga inti (exstended family) yang merupakam kelompok sosial terkecil dari masyarakat, yang terbentuk berdasarkan pernikahan dan terdiri dari seorang ayah (suami), ibu (istri), dan anak-anak yang di dalamnya dilandasi oleh cinta dan kasih sayang di antara anggotanya. Keluarga inti sebagai kelompok primer yang terkait oleh hubungan intim mempunyai fungsi utama sebagai berikut:

1. Pemberian afeksi, dukungan, dan persahabatan

2. Memproduksi dan membesarkan anak

3. Meneruskan norma-norma kebudayaan, agama, dan moral pada yang muda Mengembangkan kepribadian

4. Membagi dan melaksanakan tugas-tugas di dalam keluarga maupun di luarnya ${ }^{26 .}$

Semua fungsi tersebut melibatkan partisipasi perempuan untuk melaksanakan peranannya sebagai ibu rumah tangga meskipun laki-laki

\footnotetext{
${ }^{26}$ Utami Munandar, Emansipasi dan Peran Ganda Wanita Indonesia Suatu Tinjauan Psikologis, Jakarta: Universitas Indonesia (Jakarta: UI-press, 1985). H. 39.
} 
sebagai suami ikut andil di dalamnya. Mulai dari fungsi yang pertama sampai yang terakhir dilakukan oleh perempuan sebagai ibu rumah tangga terhadap anakanak mereka semenjak anak-itu lahir sampai masuk sekolah dan hingga dewasa. Hal ini dapat kita mengerti bahwa di kalangan perempuan sebagai ibu rumah tangga mempunyai anggapan bahwa tugas utama seorang ibu adalah merawat anaknya, antara lain merawat, menjaga kesehatannya, memperhatikan gizi makanan, mengusahakan agar pakaian anak selalu rapih dan bersih. Mengajarkan sopan santun serta tata pergaulan dan sebagainya.

Selain itu perempuan sebagai orang tua dan ibu rumah tangga mempunyai jalinan hubungan yang kuat dengan anak dalam proses pembentukan dan perkembangan kepribadian anak, sebab orang tua terutama ibulah yang merupakan orang pertama dan dikenal oleh Si Anak. Melalui orang pertama inilah Si Anak mendapatkan kesan-kesan pertama tentang dunia luar. Bagi seorang bayi/anak kecil hubungan afektif dengan orang tuanya merupakan factor penentu agar ia dapat "survive".

Menurut hasil penyelidikan Rene Spitz dalam kutipan Utami dinyatakan, bahwa tanpa cinta kasih ini seorang bayi tidak bisa hidup terus, oleh karena itu memperoleh cinta kasih merupakan kebutuhan dasar seperti makan dan tidur. Pemenuhan terhadap kebutuhan ini tentu saja tidak bisa lepas dari orang tua terutama perempuan sebagai ibunya. Seorang ibu dalam hal ini membimbing terhadap tingkah laku anak mereka dengan berbagai cara misalnya saja menerima, menyetujui, membenarkan ataupun menolak, melarang dan sebagainya terhadap tingkah laku anak mereka. Pemberian nilai tingkah laku yang seperti ini maka terbentuklah dalam anak tentang norma-norma dan nilai-nilai social dengan berbagi jenis dan tingkatannya yang secara sosiologis mencakup cara, kebiasaan, tata kelakuan, dan adat istiadat. Dengan demikian terbentuklah hati nurani anak yang kemudian akan mengarahkan ke tingkah laku selanjutnya dalam kehidupan bermasyarakat.

Peran perempuan dalam keluarga selain berkontribusi penting dalam proses pembentukan kepribadian dan mental anak seperti tercermin pada paparan di atas, ia juga bertugas melaksanakan fungsinya yang berkaitan 
Transformasi, Vol. 13, No. 1, Januari 2017: 62 - 79

dengan status istri bagi suaminya. Hal ini bisa kita pahami karena keluarga itu terbentuk jika ada ikatan perkawinan antara seorang laki-laki dan perempuan. Jika ini terjadi maka dua mahluk dari seks yang berlainan, dengan cirri-ciri kepribadian yang berbeda, mengikat diri untuk selanjutnya mereka hidup bersama. Oleh karena itu antara kedua belah pihak harus ada masa "penyesuaian kepribadian". Adapun proses penyesuaian diri ini dilakukan secara terus-menerus.

\section{Peran Perempuan dalam Kehidupan Sosial}

Perempuan pada masyarakat modern dewasa ini dintuntut untuk berpartisipasi secara aktif dalam kehidupan sosial, yang merupakan salah satu azas pemerataan yang dituju dalam salah satu makna keadilan. Perempuan dalam hal ini mendapat kesempatan untuk mewujudkan potensi-potensinya secara optimal. Hal ini merupakan kebutuhan perempuan yang harus dipenuhinya, dan tidak sedikit pula bagi perempuan Indonesia yang telah berupaya memenuhi kebutuhan tersebut baik yang masih berstatus "lajang" maupun yang telah berumah tangga.

Kondisi seperti ini bisa kita cermati secara empirik, bahwa pada zaman dahulu kebutuhan perempuan pada umumnya terbatas pada kebutuhan fisiologis, kebutuhan akan rasa aman, dan perlindungan, kebutuhan akan cinta dan"belonging" (social needs), sedangkan pada masa sekarang dapat mengikuti pendidikan, bekerja di kantor ataupun menduduki jabatan kepemimpinan, dan bahkan kebutuhan akan prestasi serta perwujudan diri, aktualisasi diri bisa dirasakan dan dipenuhi oleh sebagian besar perempuan di Indonesia ${ }^{27}$.

Paparan di atas menunjukkan bahwa status perempuan di Indonesia telah mencapai perkembangan yang cukup tinggi. Dengan status tersebut, seorang perempuan dapat menentukan sifat dan tingkatan kewajiban serta tanggung jawab di dalam suatu kelompok masyarakat. Di samping itu juga

${ }^{27}$ Fauzie Ridjal dkk., Dinamika Gerakan Perempuan di Indonesia. (Yogyakarta: Tiara Wacana, 1993), h. 126. 
menentukan hubungan antara atasan dan bawahan terhadap anggota lain dalam kelompok masyarakat di mana mereka terlibat di dalamnya. Status itu sendiri merupakan serangkaian tanggung jawab serta hak-hak yang sudah ditentukan dalam masyarakat. Sedangkan pola tingkah laku yang diharapkan dari orang-orang pemangku status dinamakan peranan. Selanjutnya perananperanan sosial saling berpadu sedemikian rupa sehingga saling tunjangmenunjuang secara timbal balik di dalam hal yang menyangkut tugas, hak, dan kewajiban. Oleh karena itu suatu penampilan peranan status (status role performance) adalah proses penunjukkan atau penampilan dari status dan peranan sebagai unsure struktur sosial di dalam kehidupan sosial.

Posisi dan kedudukan perempuan dalam kehidupan bermasyarakat dan bernegara sudah sangat jelas yakni sebagai anggota masyarakat dan sebagai warga negara yakni memiliki sejumlah hak dan kewajiban. Tidak ada perbedaan antara laki-laki dan perempuan. Perintah Allah untuk berbuat adil dalam seluruh bidang kehidupan, baik ranah domestik maupun publik sangat tegas dan tandas, keadilan mesti ditegakkan. Keadilan merupakan prinsip ajaran Islam yang mesti ditegakkan dalam menata kehidupan manusia, prinsip itu harus selalu ada dalam setiap norma, tata nilai dan prilaku umat manusia di mana pun dan kapan pun ${ }^{28}$.

Menurut Sayid Muhammad Husain Fadhlullah menyatakan, perempuan dalam pandangan Islam tidak meletakkan batasan dan perbedaan antara lakilaki dan perempuan pada tingkat hakikat kemanusian. Laki-laki dan perempuan merupakan esensi kemanusiaan yang satu, hanya perbedaan satu-satunya adalah perbedaan yang ada kaitannya dengan $\mathrm{fisik}^{29}$. Berpartisispasi dalam kehidupan sosial dan bertemu dengan kaum pria merupakan sunnah kehidupan manusia dan menjadi karakter kehidupan masyarakat. Sejak dahulu Allah menciptkan laki-laki dan perempuan untuk memakmurkan bumi secara

\footnotetext{
${ }^{28}$ Musda Mulia, Islam dan Inspirasi Kesetaraan Gender, (Yokyakarta: Kibar Press, 2007), h.
}

${ }^{29}$ Lihat Sayid Muhammad Husain Fadhlullah, Dunia Perempuan dalam Islam ( Dunia alMar'ah) diterjemahkan oleh Muhammad Abdul Qadir Alkat, (cet. I, Jakarta : Lentera, 2000), h.4 
Transformasi, Vol. 13, No. 1, Januari 2017: 62 - 79

bersama-sama yang akhirnya lahir kehidupan yang berjalan dalam suasana mantap ${ }^{30}$.

Oleh sebab itu, sudah seharusnya perempuan dilihat sebagai pendorong kemajuan bangsa atau kemajuan bangsa. Hal ini didasarkan pada sebuah pemahaman bahwa jika perempuan-perempuan yang selama ini ditempatkan "secara agak paksa" hanya sebagai pengurus anak, pengatur keuangan keluarga, pengatur jadwal suami dan pemberi semangat anak-anak dan suami tidak bekerja maksimal, maka bangsa ini tidak akan maju.

Kewajiban perempuan yaitu amar ma'ruf nahi mungkar, yang menganjurkan perempuan agar berpatisipasi dalam melakukan kritik sosial, membetulkan yang salah, memperbaiki yang kurang, meluruskan yang bengkok, memulai dari lingkungan keluarga, tetangga, dan, masyarakat sekitarnya. Menyuruh yang ma'ruf termasuk bukan saja menyebarkan kesalehan dan ibadah ritual, tetapi menyuruh meningkatkan gizi makanannya, meningkatkan ilmu pengetahuan dan mewujudkan cita-citanya. Melarang yang mungkar adalah menghindarkan masyarakat dari pengaruh negatif yang merusak kwalitas hidup mereka baik dari segi material dan spiritual, emosional dan intelektual, individual dan sosial ${ }^{31}$.

\section{PROSES PELAKSANAAN KEGIATAN}

\section{A. Strategi Pemberdayaan}

Kerangka pemecahan masalah tahap pertama adalah pendekatan sosial ekonomi. Hal ini dilakukan dengan observasi langsung pada masyarakat sekaligus melakukan pemetaan potensi usaha yang isa dikembangkan di desa tersebut Tahap kedua adalah pelatihan.

Pengabdian kepada masyarakat ini dapat membantu masyarakat (keluarga di masyarakat) dalam membentuk, mengisi dan mengembangkan peran perempuan dalam kehidupan sosial. Pengutan kesadaran peran

\footnotetext{
1999), h.1-3.

31 Jalaluddin Rahmat, Islam Alternatif : Ceramah -Ceramah di Kampus, ( Cet; XI, Bandung : Mizan, 2003), h.135.
}

${ }^{30}$ Abdul Halim Abu Syuqqah, Kebebasan Perempuan, ( Cet.II. Jakarta : Gema Insan Press, 
perempuan dalam khehidupan social masyarakat Desa Loloan dilakukan dengan mengembangkan kemampuan kewiraushaan dan pelatikan keterampilan lainnya yang memiliki nilai ekonomi. Kegiatan ini merupakan wadah bagi perempuan atau masyarakat untuk bersama-sama membantu mengatasi permasalahan yang dihadapi. Adapun bentuk kegiatan yang dilakukan berupa pelatihan wirausaha, pendidikan dan keterampilan, peningkatan kesehatan serta dukungan pelestarian lingkungan sebagai upaya memperbaiki kualitas sumber daya manusia.

Langkah pertama yang dilakukan tim adalah melakukan pengabdian pada masyarakat dengan membuka ruang konsultasi dan advokasi untuk meningkatkan kesadaran dan komitmen para pejabat daerah, camat, kepala desa, instansi terkait pentingnya pentingnya penguatan kesadaran peran perempuan dalam kehidupan social. Sebab, perempuan juga bagian dari masyarakat yang secara manusiawi memiliki perasaan yang sama dengan kaum laki-laki.

Langkah selanjutnya, dilakukan pendataan dan observasi seluruh sasaran keluarga yang tinggal di wilayah Desa Loloan. Pendataan yang seksama itu bertujuan untuk mengidentifikasi dan menempatkan perempuan sasaran dan memetakannya dalam kondisi atau posisi sesuai dengan indikator yang dipergunakan, misalnya ditempatkan sebagai kelompok keluarga prasejahtera, keluarga sejahtera I, keluarga sejahtera II, III, dan III Plus. Untuk kelompok pra sejahtera dan sejahtera I dianalisis masalah dan kebutuhan mereka untuk meningkat pada posisi yang lebih baik. Kelompok keluarga sejahtera II sampai III Plus diajak ikut serta membantu keluarga yang kurang beruntung untuk mengatasi masalah melalui pendampingan. Setelah rencana kegiatan terbentuk baru kemudian dilanjutkan dengan pendataan dan ditutup dengan menganalisis temuan. Untuk mencapai kondisi yang diharapkan perlu ditempuh beberapa strategi. Adapun strategi yang dimaksud meliputi:

Pertama, yaitu melakukan mapping sosia/ dengan cara silaturrahmi atau kunjungan ke rumah-rumah, sehingga diketahui aktifitas sehari-hari mereka 
Transformasi, Vol. 13, No. 1, Januari 2017: 62 - 79

dan berbagai persoalan yang dihadapi didukung dengan transeks (telusur wilayah). Kemudian, bersama-sama tim menemukan care problem dan main problem. Dari core problem ini akan muncul pemetaan problem mana yang mendesak yang harus ditindaklanjuti.

Kedua, perencanaan program yaitu bersama-sama menentukan rencana kegiatan yang akan dilaksanakan untuk menyelesaikan persoalan-persoalan yang telah terumuskan.

Ketiga pelaksanaan program yaitu mulai menjalankan program-program yang sudah dirancang dalam tahap perencanaan.

Keempat, evaluasi program, yaitu mengetahui seberapa jauh hasil yang telah dicapai dalam pelaksanaan program dengan tujuan mendapatkan umpan balik sebagai bahan untuk dijadikan renungan, catatan dan pemikiran dalam rangka penyusunan program pemantapan dan sosialisasi hasil kepada pihakpihak terkait.

Adapun Langkah-langkah operasional yang dilakukan dalam menjalankan strategi di atas meliputi:

1. Identifikasi Masalah/Assessment

Pertama, tim peniliti berkunjung dari rumah ke rumah di mana Remaja Putus Sekolah dari Keluarga Kurang mampu berada. Yang dilakukan pada tahap identifikasi antara lain: 1) melakukan analisis sosial, ekonomi, budaya, dan lainnya, untuk mengetahui kebutuhan, potensi, peluang serta permasalahan yang ada dengan menggunakan teknik FGD dan hasilnya terumuskan dalam analisis pohon masalah, dari hasil analisa pohon masalah kemudian dibuat matrik rangking penyeselaian masalah ; 2) Melakukan analisis pihak terkait (Stake holders analysis) dengan teknik FGD dan hasilnya adalah diagram venn yang menunjukan hubungan kelembagaan; dan 3). Melakukan analisis keunggulan yaitu mengenali keunggulan yang dimiliki oleh komunitas. Dalam langkah ini peneliti mulai menemukan faktor apa yang bisa dikembangkan dengan melihat peluangpeluang yang ada pada masyarakat Desa Loloan Kecamatan Bayan Kabupaten Lombok Utara. 
2. Perencanaan program/Disain Proyek Identifikasi dilanjutkan

Setelah dilakukan identifikasi kebutuhan, permasalahan yang dihadapi serta kekuatan dan peluang yang dimiliki, maka langkah selanjutnya adalah mendisain program secara bersama-sama dengan masyarakat. Berdasarkan hasil analisis kebutuhan, disusunlah dalam bentuk program yang dilingkupi draft logical framework untuk bahan awal yang akan dibahas kembali dalam lokakarya yang melibatkan berbagai pihak terkait untuk merumuskan dan memutuskan sasaran (goal), tujuan antara (purpose), keluaran (out put) serta asumsi-asumsi penting, serta siapa pelaksana program ini. Perlu didentifikasi baik pengetahuan, ketrampilan, teknis, komitmennya dan bagaimana melakukan program tersebut. Dengan demikian rencana kerja secara spesifik perlu disusun berdasarkan keluaran program dan indikator keberhasilan sebagaimana yang tertuang dalam kerangka kerja logis dan strategi yang dilaksanakan.

3. Pelaksanaan dan Pemetaan Program

Dalam pelaksanaan program ada beberapa pokok kegiatan penting yaitu, 1) Mengadakan sosialisasi program kepada Masyarakat Subyek Pemberdayaan, 2) melakukan persiapan sosial, yaitu kegiatan sebagai tindak lanjut dari identifikasi awal melalui berbagai pertemuan untuk memperoleh persepsi yang sama. Evaluasi Program

Evaluasi disini bertujuan mendapatkan informasi tentang seberapa jauh keberhasilan program yang dijalankan, kendala apa yang dihadapi serta upaya apa yang harus ditempuh. Evaluasi dilakukan secara terus menerus sebagai upaya refleksi sebagai pijakan aksi-aksi berikutnya.

\section{B. Tahap Pelaksanaan}

Penguatan kesadaran peran perempuan dilakukan dengan memeberikan pelatihan life skill berupa cara pembuatan telur asin. Pada awalnya dengan adanya pelatihan pembuatan telur asin yang praktis bagi perempuan peserta pelatihan merasasa sangat terbantu. Kegiatan ini dilakukan secara berkelompok. 
Transformasi, Vol. 13, No. 1, Januari 2017: 62 - 79

Kegiatan dimulai dengan kegiatan workshop kewirausahaan dengann tujuan menyajikan informasi kepada kaum perempuan yang terdaftar sebagai peserta untuk menumbuhkan potensi-potensi kewirausahaannya. Pada program pengambdian kepada masyrakat ini Setelah workshop berlangsung baru kemudin dilanjutkan dengan gelar pelatihan pembuatan telur asin. Aktifitas pelatihan pembuatan telur asin berlangsung selama satu hari. Masingmasing peserta didampingi secara individu, mengingat kemampuan peserta yang berbeda.

\section{HASIL KEGIATAN}

Pengamatan dan wawancara yang dilakukan bahwa sebagian besar mata aktivitas utama kaum perempuan masyarakat Desa Loloan adalah petani, berternak berupa usaha sambilan. Jenis ternak yang utama dipelihara adalah itik, disamping itu ternak sapi, kambing dan domba. Hasil pengamatan dilapangan Desa Loloan merupakan daerah yang potensi untuk budiadaya ternak itik, karena daerah tersebut merupakan daerah yang tingkat ketersediaan air tinggi, persawahan dan perkebunan yang banyak terdapat sumber pakan baik yang berasal dari limbah hasil pertanian maupun hasil perkebunan, hal ini memungkinan produk yang dihasilkan dari budidaya ternak itik yaitu berupa telur juga bisa meningkat.

Sebelum melaksanakan kegiatan pengabdian terlebih dahulu sosialisasi untuk menyebarluaskan informasi kepada masyarakat Desa Loloan, bahwa didesa ini akan dilakukan pengabdian masyarakat yng dilakukan oleh dosen IAIN Mataram dan mahasiswa. Sosialisasi dilakukan dengan cara memberi informasi langsung kepada kepala desa dan kepala dusun. Sosialiasi ini bertujuan agar kepala desa maupun kepala dusun menyampaikan informasi ke masyarakat melalui kegiatan di Desa Loloan seperti pengajian, pertemuan rutin dan lain sebagainya. Khalayak sasaran adalah kaum perempuan yang selama ini minim keterlibatan dalam segala bentuk kegiatan masyarakat.

Perkenalan diawali dengan menyebutkan satu persatu tim pelaksana pengabdian, termasuk mahasiswa yang terlibat. Hal ini bertujuan menjalin 
keakraban dan kekeluargaan sehingga pelaksanan pengabdian dapat berjalan sesuai dengan harapan. Sedangakan kata sambutan dari dosen pelaksana bertujuan memberi informasi kepada masyarakat bahwa tim pelaksana melakukan pelatihan dan pembinaan secara berkelanjutan dan berkesinambungan.

Kegiatan pelatihan disampaikan oleh dosen dengan peserta yang hadir dalam acara tersebut sebanyak 15-20 orang. Selama kegiatan pelatihan disampaikan Beberapa hal yang dilakukan untuk meningkatkan kesadaran peran perempuan dalam kehidupan social, di samping itu juga dalam rangka meningkatkan perekonomian ekonomi masyarakat melalui pelatihan pembuatan telur asin.

Adapun hal yang dilakukan untuk meningkatkan kesadaran peran perempuan dalam kehidupan social Desa Loloan dalam hal ini penuyuluh beserta tim dari mahasiswa memberikan informasi tentang beberapa kandungan gizi dalam telur asin yang menyebabkan memiliki nilai ekonomi yang tinggi adalah :

1. Memberikan pengetahuan tentang tingginya nilai gizi telur dan telur asin terutama kandungan protein untuk mencukupi gizi balita, anak-anak, orang dewasa dan juga lansia. Pengetahuan diberikan melalui pelatihan dan liflet yang diberikan. Konsumsi telur asin sangat cocok sebagai cemilan ataupun lauk untuk makan nasi.

2. Memberikan pengetahuan tentang khasiat telur asin, diantaranya: mengawetkan telur, membuang rasa amis, obat diare/sakit perut dan maag serta menciptakan rasa khas dan gurih pada telur asin.

3. Memberikan pengetahuan tentang cara pembuatan telur asin, terutama telur asin rendah sodium, juga telur asin dengan abu sekam/abu gosok, telur asin direndam dalam larutan garam dan telur asin dengan cara injeksi. Hal ini bertujuan untuk memudahkan masyarakat dalam membuat telur asin sesuai dengan kebutuhan, peralatan dan bahan yang tersedia. Sehingga kebutuhan gizi terhadap telur asin sehari-hari dapat segera tercukupi dengan membuat sendiri. 
Transformasi, Vol. 13, No. 1, Januari 2017: 62 - 79

4. Masyarakat sangat antusias bertanya bagaimana mendapatkan abu sabut kelapa yang berkualitas, berbagai macam cara pembuatan telur asin dan biaya yang dibutuhkan dalam pembuatan telur asin serta cara menghasilkan telur asin yang bermutu tinggi.

5. Membagikan telur asin yang sudah dibuat. Hal ini untuk lebih meningkatkan kelebih sukaan masyarakat akan telur asin yang telah dipraktekkan dan meningkatkan konsumsi telur sebagai sumber protein hewani.

6. Mengubah pola pikir peternak untuk tidak selalu menjual seluruhnya telur itik yang dihasilkan tapi dibuat telur asin dan dikonsumsi untuk memenuhi kebutuhan gizi keluarga. Juga mengubah pola pikir masyarakat untuk mengalihkan konsumsi makanan fast food menjadi makanan yang bergizi tinggi yaitu telur asin yang bisa dibuat sendiri.

Adapun yang dilakukan untuk meningkatkan kesadaran peran perempuan dalam kehidupan social pada sektor ekonomi sehingga mampu berpengaruh pada perekonomian masyarakat Desa Loloan adalah:

a. Memberikan pengetahuan tentang pentingnya telur itik dijadikan telur asin untuk meningkatkan ekonomi masyarakat, apalagi telur hasil peternakan sendiri. Jika satu butir telur dijual Peternak Rp 1200,- sampai 1500,- maka jika dijual dalam bentuk telur asin Rp 2000,- ketangan pedagang dan Rp 2500,- langsung kekonsumen. Maka didapat keuntungan sekitar Rp 500 sampai $1300,-$.

b. Memberikan peluang pasar yang masih perawan untuk dikembangkan sebagai konsumen telur asin yaitu warung, dijadikan oleh-oleh produk khas kabupaten Lombok Utara mengingat potensi wisatanya yang sangat tinggi. Selain itu hasil produksi telur asin bisa dipasarkan di pusat-pusat keramaian di ibu kota kabupaten Lombok Utara yang lokasinya tidak terlalu jauh dari desa Loloan.

c. Mempraktekkan berbagai macam cara pembuatan telur asin terutama telur asin rendah sodium, juga telur asin dengan abu sekam, telur asin direndam dalam larutan garam dan telur asin injeksi. Khusus telur asin injeksi bisa 
dikembangkan untuk telur asin aneka rasa. Ini bertujuan untuk memudahkan dalam mengelola bisnis telur asin sesuai permintaan pasar.

d. Masyarakat tidak merasa kesulitan dalam mendapatkan bahan baku telur yaitu dari hasil ternak itik ataupun dari pasar yang dekat dari lokasi.

e. Masyarakat dapat memanfaatkan limbah hasil pertanian yaitu sabut kelapa dan sekam sebagai bahan membuatan telur asin.

Pelatihan ini cukup berhasil, walaupun dari jumlah beserta hanya tidak sebanyak yang telah direncanakan akan tetapi jumlah pertanyaan yang muncul selama diskusi cukup banyak. Pada peserta sangat antusius dengan pelatihan yang dilakukan oleh tim pengabdian.

Pembuatan telur asin rendah sodium hanya membutuhkan telur itik dan abu sabut kelapa. Telur itik sangat baik untuk dibuat telur asin. Dikemukakan oleh Astawan (2006) selain baunya yang lebih amis, telur itik juga mempunyai pori-pori kulit yang lebih besar, sehingga sangat baik untuk diolah menjadi telur asin untuk menciptakan rasa yang khas dan gurih. Pemilihan bahan baku sangat penting untuk diperhatikan. Telur itik yang akan digunakan untuk pembuatan telur asin haruslah telur yang masih baru dengan umur 10 jam kurang atau maksimal 48 jam. Hal ini untuk menghasilkan telur asin yang bermutu. Telur itik yang besar mempunyai cangkang lebih tipis dari yang kecil. Abu sabut kelapa digunakan adalah abu yang telah mengalami pembakaran berulang-ulang, sehingga warnanya abu-abu. Sedangkan jika menggunakan garam, maka pilih garam yang kristal garamnya tidak terlalu besar dan tidak terlalu kecil. Jika kristal garamnya terlalu kecil, maka garam tidak sempurna masuk ke dalam telur. Tanda sempurna masuk garam ke dalam telur dapat diperhatikan dari lapisan mentega pada kuning telur.

\section{KESIMPULAN}

Perempuan mestinya memiliki peran yang lebih besar dalam kehidupan masyarakat. Perempuan juga memiliki potensi yang akan berguna pembangunan masyarakatnya. 'Mestinya tak ada diskriminasi terhadap perempuan. Bahkan di dalam Al-quran juga dinyatakan bahwa tak ada pembedaan antara perempuan 
Transformasi, Vol. 13, No. 1, Januari 2017: 62 - 79

dan laki-laki. Penilaian yang berbeda didasarkan pada tingkat keimanannya," Perempuan akan mampu berkiprah dalam masyarakat di berbagai bidang baik ekonomi, pendidikan, teknologi, bahkan politik. Meski ia pun menyatakan bahwa perempuan juga memiliki kewajiban menyeimbangkan antara kegiatannya di luar dengan kewajiban bagi keluarganya. Peran dan tugas perempuan dalam keluarga secara garis besar dibagi menjadi peran perempuan sebagai ibu, perempuan sebagai istri, perempuan sebagai anak, dan anggota masyarakat.

Di samping itu, perempuan harus menguasai cara atau teknik memainkan peran atau melaksanakan tugasnya, disesuaikan dengan setiap situasi yang dihadapinya. Sebagai ibu, mendidik anak-anak harus mengetahui porsi yang tepat dalam memberikan kebutuhan-kebutuhan anaknya, yang disesuaikan dengan tahap perkembangannya. Sikap maupun perilakunya harus dapat dijadikan contoh bagi anak-anaknya. Sebagai seorang istri, perempuan harus menumbuhkan suasana yang harmonis, tampil bersih, memikat dan mampu mendorong suami untuk hal-hal yang positif. Sebagai anggota masyarakat, perempuan diharapkan peran sertanya dalam masyarakat.

Keberhasilan melakukan peran di atas, tentunya bukan merupakan hal yang mudah, yang penting adalah kemauan dan usaha untuk selalu belajar. Oleh karena itu, hendaknya orang tua menanamkan kepada diri anak semenjak usia dini tentang makna kejujuran, pengorbanan, menolong sesama, dan nilai-niali religiulitas lainnya seperti ketaatan beribadah kepada Allah. Jika semua nilai-nilai ini ditanamkan sejak kecil, nilai-nilai tersebut akan mengakar dalam jiwa anak dan dapat menjadi pencegah dirinya dalam melakukan hal-hal yang buruk.

\section{DAFTAR PUSTAKA}

Abdulsyani. Sosiologi Skematika, teori dan terapan, Cetakan ke-2, Jakarta: Bumi Aksara, 2002.

Abdul Halim Abu Syuqqah, Kebebasan Perempuan, Cet. II. Jakarta : Gema Insan Press, 1999).

Abercrombie, Nicholas Stephen Hill, Bryan S.Turner, Kamus Sosiologi, Pustaka Pelajar, Yogyakarta, 2010. 
Aida Vitayala S. Hubeis, Pemberdayaan Perempuan dari Masa ke Masa. IPB Press, Bogor, 2010.

Fauzie Ridjal dkk. Dinamika Gerakan Perempuan di Indonesia. Yogyakarta: Tiara Wacana. 1993.

Jalaluddin Rahmat, Islam Alternatif: Ceramah -Ceramah di Kampus, Cet; XI, Bandung: Mizan, 2003

Musda Mulia, Islam dan Inspirasi Kesetaraan Gender, Yokyakarta: Kibar Press, 2007.

Sayid Muhammad Husain Fadhlullah, Dunia Perempuan dalam Islam (Dunia alMar'ah) diterjemahkan oleh Muhammad Abdul Qadir Alkat, cet. I, Jakarta : Lentera, 2000.

Scott, John Sosiologi : The Key Concept. Rajawali Pers, Jakarta, 2011.

Utami Munandar, Emansipasi dan Peran Ganda Wanita Indonesia Suatu Tinjauan Psikologis, Jakarta: Universitas Indonesia (UI-press). 1985. 